Biol. Neonate 1972;21:I-VI

\title{
Contents, Vol. 21, 1972
}

\section{Contents}

Alexander, D. Pauline; Britton, H. G.; Cohen, N. M., and Nixon, D. A.: The Permeability of the Sheep Placenta to Insulin: Studies with the Perfused

Placental Preparation 361

Alexander, D. Pauline ; Forsling, Mary L.; Martin, Marion J.; Nixon, D. A.; Ratcliffe, J. G.; Redstone, D., and Tunbridge, D.: The Effect of Maternal Hypoxia on Fetal Pituitary Hormone Release in the Sheep 219

Allen, J. R.: see Kerr, G. R.

Armstrong, M. D.: see Stave, U.

Auld, P. A. M.: see Krauss, A. N.

Aures, D.: see Kunze, E.

Battaglia, F. C.: see Douglas Jones, M. jr.

Beard, R. W.: see Johnston, D. I.

Blackburn, M. G.; Orzalesi, M. M., and Pigram, P.: Effect of Light and Bilirubin on Fetal Red Blood Cells in vitro 35

Blackmore, D. W.: The Effect of Limited, Moderate and Lengthy Daily Separa tion from the Mother during the Early Postnatal Period of the Rat on Concurrent and Subsequent Growth, and on Concurrent Oxygen Con sumption at, as well as below, Thermal Neutrality 268

Blanc, W. A.: see Cardasis, Constance, A.

Bloom, S. R.: see Johnston, D. I.

Bowe, E. T.: see Hyman, A. I.

Brachet, E. A.: Glucose Uptake and Production of Pyruvate and Lactate by the Human Umbilical Cord in vitro 69

Britton, H. G.: see Alexander, D. Pauline

Budd, S.: see Slade, B.

Cammer, Wendy and Moore, C. L.: Biochemical Properties of Human Fetal Mitochondria 259

Capek, K.: see Solomon, S.

Cardasis, Constance A. and Sinclair, J. C.: The Effects of Ambient Temperature on the Fasted Newborn Rabbit. I. Survival Time, Weight Loss, Body

Temperature and Oxygen Consumption 330

Cardasis, Constance A.; Blanc, W. A., and Sinclair, J. C.: The Effects of Ambi ent Temperature on the Fasted Newborn Rabbit. II. Gross and Micro scopic Changes in Cervical and Interscapular Brown Adipose Tissue

IV

Contents

Chernick, V.: see V $\gamma$ dyasagar, D. 
Clarkson, T. W.; Magos, L., and Greenwood, M. R.: The Transport of Elemen tal Mercury into Fetal Tissues 239

Cohen, N. M.: see Alexander, D. Pauline

Cohen, N. M. and Turner, R. C.: Plasma Insulin in the Foetal Rat 107

Daniel, S. S.: see Hyman, A. I.

Dinwiddie, R. and Russell, G.: The Measurement of Effective Pulmonary Capilla ry Blood Flow in the Newborn, Using Low Concentrations of Nitrous

Oxide 83

Dobák, E.: see Mestyán, J.

Douglas Jones, M., jr.; Gresham, E. L., and Battaglia, F. C: Urinary Flow

Rates and Urea Excretion Rates in Newborn Infants 321

Dreyer, Theodore and Wolff, P. H.: Sucking, State, and Perinatal Distress in

Newborns. A Preliminary Report 16

Fekete, M.: see Mestyán, J.

Forsling, Mary L.: see Alexander, D. Pauline

Garel, J.-M. and Pic, P.: Evolution of Phosphatemia in the Rat Fetus during the

Late Stages of Gestation 369

Gartner, H.: see Kunze, E.

Gennser, G.: Influence of Hypoxia and Glucose on Contractility of Papillary

Muscles from Adult and Neonatal Rabbits 90

Gennser, G.; Lundquist, I., and Nilsson, E.: Carbohydrate Content and Glyco-

genolytic Activity in Human Placenta and Fetal Heart and Lung 148

Green, K. R.: see Johnston, D. I.

Greenwood, M. R.: see Clarkson, T. W.

Gresham, E. L.: see Douglas Jones, M., jr.

Harel, S.; Watanabe, Kathy; Linke, Ilona, and Schain, R. J.: Growth and

Development of the Rabbit Brain 381

Haworth, G.: see Hyman, A. I.

Heim, T.: see Sulyok, E.

Helander, H. F.: Gastric $\alpha$-Amylase and $\beta$-Galactosidases in Rats during the

Development 161

Heringová, A.: see Jirsová, V.

Heringová, A.; J Jrsová, V., and Polácek, K.: Bilirubin Clearance in Healthy

and Pathological Newborns 303

Hewitt, J. R.; Klein, R. M., and Lucey, J. F.: Photodegradation of Serum

Bilirubin in the Gunn Rat 112

Hyman, A. I.; Haworth, G.; Bowe, E. T.; Daniel, S. S., and James, L. S.: Effects

of Sympathetic Blockade on the Fetal Responses to Asphyxia

James, L. S.: see Hyman, A. I.

Jászai, V.: see Sulyok, E.

Jéquier, E.: see Sulyok, E.

Jirsa, M.: see Jirsová, V.

Jyrsová, V.: see Heringová, A.

Jirsová, V.; Heringová, A., and Jirsa, M.: Inhibition of Choleresis and Bilirubin

Excretion in Rats Caused by Sera of Diabetic Mothers 296

Contents V 
Jonston, D. L; Bloom, S. R.; Greene, K. R., and Beard, R. W.: Failure of the Human Placenta to Transfer Pancreatic Glucagon 375

Jonxis, J. H. P.: see Nijhof, W.

KACiUBA-UáciLKO, Hanna: Hormonal Regulation of Thermogenesis in the New-

Born Pig. The Effect of Ambient Temperature on Urinary Catecholamine

Excretion 245

Keenan, W. J.; Light, I. J., and Sutherland, J. M.: Effects of Exogenous

Epinephrine on Glucose and Insulin Levels in Infants of Diabetic

Mothers 44

Kerr, G. R.; Tyson, I. B.; Allen, J. R.; Wallace, J. H., and Scheffler, G.: Defi

ciency of Thyroid Hormone and Development of the Fetal Rhesus Mon

key. I. Effect on Physical Growth, Skeletal Maturation and Biochemical

Measures of Thyroid Function 282

Klein, R. M.: see Hewitt, J. R.

Krauss, A. N.; Thibeault, D. W., and Auld, P. A. M.: Acid-Base Balance in

Cerebrospinal Fluid of Newborn Infants 25

Kunze, E.; Schauer, A.; Aures, D., and Gartner, H.: Influence of Cortisol-

21-Hemisuccinate on the Specific Histidine Decarboxylase of the Fetal

Rat Liver $\quad 463$

Lardinois, R.: see Nakamura, H.

Lardynois, R.: see Tuilié, M.

Larroche, Jeanne-Claudye: Sub-Ependymal Pseudo-Cysts in the Newborn 170

Light, I. J.: see Keenan, W. J.

Lind, J.: see Yao, Alice C.

Linke, Ilona: see Harel, S.

Lypp, Jo Ann M. and Rudolph, A. M.: Sympathetic Nerve Development in the

Rat and Guinea-Pig Heart 76

Lucey, J. F.: see Hewitt, J. R.

Lundquist, I.: see Gennser, G.

Magos, L.: see Clarkson, T. W.

Maines, M. D.: see Short, C. R.

Martin, Marion J.: see Alexander, D. Pauline

Mestyán, J.: see Soltész, Gy.

Mestyán, J.; Soltész, Gy. ; Dobák, E.; Fekete, M., and Schultz, K.: The Post-

Natal Changes in the Circulating Free Amino Acid Pool in the Newborn

Infant. IV. The Relationship between the Changes of the Plasma Amino

Acid Ratio, $\alpha$-Amino-N, Free Fatty Acid and Blood Glucose Concentra

tion after Birth

Moore, C. L.: see Cammer, Wendy

Nakamura, H. and Lardinois, R.: Unbound Bilirubin in Icteric Newborns 400

Nijhof, W.; Ronda, G. J., and Jonxis, J. H. P.: The Synthesis of Haemoglobins

$\mathrm{A}$ and $\mathrm{F}$ in the Calf 120

Nilsson, E.: see Gennser, G.

Nixon, D. A.: see Alexander, D. Pauline

Orzalesi, M. M.: see Blackburn, M. G.

Pic, P.: see Garel, J.-M. 
Pigram, P.: see Blackburn, M. G.

VI

Contents

Polácek, K.: see Heringová, A.

Rietveld, W. J.: see Stulc, J. J.

Ronda, G. J.: see Nijhof, W.

Rubecz, I.: see Soltész, Gy.

Rudolph, A. M.: see Lipp, Jo Ann M.

Russell, G.: see Dinwiddie, R.

Ryser, G.: see Sulyok, E.

Schain, R. J.: see Harel, S.

Schauer, A.: see Kunze, E.

Scheffler, G.: see Kerr, G. R.

Schultz, K.: see Mestyán, J.

Schultz, K.: see Soltész, Gy.

Short, C. R.; Maines, M. D., and Westfall, B. A.: Postnatal Development of

Drug-Metabolizing Enzyme Activity in Liver and Extrahepatic Tissues

of Swine 54

Sinclair, J. C: see Cardasis, Constance A.

Slade, B. and Budd, S.: Localization of $\alpha$-Fetoprotein in Fetal and Newborn

Rabbits $\quad 309$

Soeteman, D. W.: see Stulc, J. J.

Solomon, S. and Capek, K.: Increased Food Availability and Renal Development

of Neonatal Rats

9

Soltész, Gy. : Mestyán, J.; Schultz, K., and Rubecz, I.: Glucose Disappearance

Rate and Changes in Plasma Nutrients after Intravenously Injected

Glucose in Normoglycaemic and Hypoglycaemic Underweight Newborns 184 Soltész, Gy. : see

Mestyán, J. Soltész, G.: see Sulyok, E. Stave, U. and Armstrong, M. D.: Perinatal Changes of

Plasma Free Amino

Acids in Normal and Hypoxic Rabbits

436

Stulc, J. J.; Rietveld, W. J.; Soeteman, D. W., and Versprille, A.: The Trans-

placental Potential Difference in Guinea-Pigs 130

Sulyok, E.; Heim, T.; Soltész, G., and Jászai, V.: The Influence of Maturity on

Renal Control of Acidosis in Newborn Infants 418

Sulyok, E.; Jéquier, E., and Ryser, G.: Effect of Relative Humidity on Thermal

Balance of the Newborn Infant 210

Sutherland, J. M.: see Keenan, W. J.

Thibeault, D. W.: see Krauss, A. N.

Tuilié, M. and Lardinois, R.: The Binding of Unconjugated Bilirubin by Human

Sera and Purified Albumins 447

Turner, R. C.: see Cohen, N. M. Tyson, I. B.: see Kerr, G. R. Versprille, A.: see Stulc, J. J.

Vidyassagar, D. and Chernick, V.: Placental Transfer of Metopirone

Wallace, J. H.: see Kerr, G. R.

Watanabe, Kathy: see Harel, S.

Westfall, B. A.: see Short, C. R.

Wolff, P. H.: see Dreier, Theodore 
Yao, Alice C. and Lind, J.: Blood Volume in the Asphyxiated Term Neonate ... 199 